\title{
Digital economy: theoretical and legal enforcement issues in terms of regional aspect
}

\author{
Elena Voskresenskaya ${ }^{1, *}$, Lybov Vorona-Slivinskaya ${ }^{2}$, and Lybov Achba ${ }^{3}$ \\ ${ }^{1}$ Peter the Great St.Petersburg Polytechnic University, 29, Polytechnicheskaya str., 195251, St. \\ Petersburg, Russia \\ ${ }^{2}$ Saint Petersburg State University of Architecture and Civil Engineering, 4, 2nd Krasnoarmeyskaya \\ str., 190005, St. Petersburg, Russia \\ ${ }^{3}$ Financial University under the Government of the Russian Federation, St. Petersburg branch, 15-17, \\ Sezzhinskaya str., 197198, St. Petersburg, Russia
}

\begin{abstract}
The study on issues of digital economy proved the current existence of the new "digital" economic reality. The traditional legal apparatus used for the statutory regulation of this new economic reality showed itself not only inefficient, but also significantly restraining the actively developing economic processes. In this regard, a plenty of practical and legal collisions occur related to the problems of identification of persons involved in civil-law transactions, property relations regarding digital economic turnover (for instance, relations concerning property rights in the field of distributed ledgers), registration of property rights and deals, regulation of banking line processes, formation of special protection models for relationships based on the use of digital technologies including issues of cybernetic and data security. The development of digital economy will inevitably influence legal principles and demand reconsidering some of doctrinal approaches to traditional legal models of regulating different types of economic activities. In this case, socially just changes in the legal regulation of economic activities should be primarily aimed at removing legal barriers that impede the development of digital economy, as well as at synchronizing legal rules with the technological features of economy's functioning.
\end{abstract}

\section{Introduction}

The economy absolutely prevails over legal regulation. Any attempts to change this by putting legal regulation over economic processes are foredoomed to inevitable failure, since such economy will rapidly and dramatically collapse. In recent decades, the widespread introduction of digital technologies caused fundamental change in the economy character. Today, the plenty of economic processes are modeled, maintained and operated according to the new management principles that are based on digital innovations: distributed registries; arrays of big data; new methods of analysis and mathematical modeling.

As a result, nowadays one can state the existence of the new "digital" economic reality, for the legal regulation of which the old legal apparatus showed itself not only ineffective,

\footnotetext{
${ }^{*}$ Corresponding author: elenvoskr@mail.ru
} 
but also restraining the actively developing economic processes.

A. V. Babkin, D. D. Burkaltseva, D. G. Kosten, Y. N. Vorobyov and others specify factors for the effective development of electronic commerce, some of which are the following: development of information and computer infrastructure, interactive communities, information resources, knowledge bases, digital environment, new forms of electronic communications, platforms for integrating business, government and society [14].

V.A. Efimushkin, T.V. Ledovskikh, E.N. Scherbakova try to determine the exact technologies that should be developed within the program "Digital Economy" on the basis of the unified cyberspace of the Eurasian Union countries. For the successful development of the digital economy in Russia within the framework of the state program "Digital Economy" the following is to be ensured: the development of state-owned, socially significant online services; transition to digital technologies of state bodies and departments; development of the Internet in the sector of individual consumers and the industrial sector; creation of domestic software, modern information and computer technologies for import substitution [5-8].

The authors of the present article payed special attention to certain legal aspects of urban development [9-12]. Thus, due to the initial demand for licensing procedures of public nature, public law prerequisites require a legal analysis of the general and distinctive features in order to improve the mechanisms of legal regulation.

\section{Materials and Methods}

The article uses the official statistical information from Rosstat (Federal Service of State Statistics) and Eurostat, on the basis of which the trends in the development of digital interaction in the sphere of business were analyzed and tools were proposed for a quantitative description of regional digital divides in Russian regions and countries of the European Union for 2010-2017. Statistical variation and localization indicators (based on Gini and Lorentz coefficients) were used as quantitative characteristics of regional differentiation.

The digitalization of economy transforms the methods of delivering and consuming goods and services, which in turn affects all spheres of human activities. The field of etrading is a relatively young direction for the statistical observation, therefore, today researchers, politicians, businessmen and other interested parties lack statistical information that could help study the economic, social and environmental consequences of the digitalization of the world. The study is aimed to describe quantitatively the development trends and the degree of regional differentiation of e-trading in the Russian Federation in terms of international comparisons.

\section{Results}

The analysis performed within the study showed the validity of the estimates of regional digital divide made on the basis of economic and statistical indicators. This approach increases the opportunities for a detailed quantitative description of processes occurring in e-trading. In addition, the authors succeeded to determine the development level of etrading in Russia comparing with the leading economies of the European Union, as well as to define the implementation extent of broadband Internet access among organizations, the involvement of Russian regions and European countries in the processes of placing and receiving orders for goods and services in the global network. The study showed that although some European countries perform better then not only Russian regions but almost 
the rest of the world, e-trading in both Russia and the European Union is developing at a comparable pace. It also should be noted that in Russia e-trading development proceeds more uniformly in terms of regional differentiation.

Both in the Russian Federation and in the European Union, digital divides are being reduced from a regional perspective, and in both cases this process occurs almost identically. The only difference lies in the initial conditions for the development of broadband access to the Internet in business. Moreover, approximately 30 regions of Russia do not correspond to the European development level. For example, in Buryatia, Yakutia, Dagestan, Novosibirsk and Kurgan Regions there are less than $70 \%$ of organizations that have broadband Internet access. Such constituent entities as Moscow (95\%) and Tambov Region (95\%) can be compared with the developed EU countries in terms of broadband Internet access introduction within the business sphere. Crimea (94\%), St. Petersburg (94\%) and the Nizhny Novgorod Region (93\%) are comparable with such EU countries as Germany (95\%), Great Britain (95\%), Estonia (95\%) and Croatia (95\%) (tables 1, 2) [13, 14].

Table 1. Comparative analysis of digital development by interval groups of indicator "Share of organizations using broadband Internet access" in 2017.

\begin{tabular}{|c|c|c|}
\hline Indicator value & $\begin{array}{c}\text { Constituent entities of the Russian } \\
\text { Federation }\end{array}$ & EU countries \\
\hline $95-100 \%$ & The city of Moscow, Tambov Region & $\begin{array}{c}\text { Finland, the Netherlands, Lithuania, } \\
\text { Denmark, Slovenia, Latvia, France, } \\
\text { Portugal, Austria, Spain, Czech } \\
\text { Republic, Belgium, Sweden, } \\
\text { Luxembourg, Cyprus, Italy, Ireland }\end{array}$ \\
\hline $90-94 \%$ & $\begin{array}{c}\text { Republic of Crimea, St. Petersburg, } \\
\text { Nizhny Novgorod Region, Orenburg } \\
\text { Region, Republic of Ingushetia, } \\
\text { Leningrad Region, Lipetsk Region, } \\
\text { Stavropol Krai }\end{array}$ & $\begin{array}{c}\text { Germany, the United Kingdom, } \\
\text { Estonia, Croatia, Norway, Hungary }\end{array}$ \\
\hline $85-89 \%$ & $\begin{array}{c}\text { Republic of Tatarstan, Yaroslavl Region, } \\
\text { Republic of Adygea, Nenets Autonomous } \\
\text { Area, Republic of Bashkortostan, } \\
\text { Republic of Karelia, Krasnodar Krai, } \\
\text { Orenburg Region, Novgorod Region, etc. }\end{array}$ & \\
\hline 84 and low & $\begin{array}{c}\text { Perm Krai, Penza Region, Kamchatka } \\
\text { Krai, Ulyanovsk Region, Arkhangelsk } \\
\text { Region, Yamalo-Nenets Autonomous } \\
\text { Area, Zabaykalsky Krai, Tula Region, } \\
\text { Tyumen Region, Krasnoyarsk Krai, etc. }\end{array}$ & Bulgaria, Greece \\
\hline
\end{tabular}

Table 2. Characteristics of the regional digital divide in Russia and the EU in terms of indicator "Share of organizations using broadband Internet access".

\begin{tabular}{|l|c|c|c|c|}
\hline \multicolumn{1}{|c|}{ Indicator } & $\begin{array}{c}\mathbf{2 0 1 0} \\
\text { Russia }\end{array}$ & EU & $\begin{array}{c}\mathbf{2 0 1 7} \\
\text { Russia }\end{array}$ & EU \\
\hline Maximum value, \% & 91.7 & 96.0 & 94.9 & 100.0 \\
\hline Minimum value, \% & 26.3 & 52.0 & 62.6 & 82.0 \\
\hline Range of variation, p.p. & 65.4 & 44.0 & 32.4 & 18.0 \\
\hline Dispersion & 123.23 & 95.5 & 47.3 & 17.7 \\
\hline Oscillation coefficient, \% & 120.3 & 52.5 & 39.0 & 18.8 \\
\hline Coefficient of variation, \% & 20.4 & 11.7 & 8.3 & 4.4 \\
\hline Gini coefficient, \% & 31.7 & 20.6 & 0.8 & 23.0 \\
\hline Lorentz coefficient, \% & 43.7 & 45.7 & 36.0 & 38.8 \\
\hline
\end{tabular}


While in terms of spread of broadband Internet access the countries of the European Union firstly have a higher development level, and secondly their development of broadband access is more uniform comparing to Russian regions, then in terms of e-trading the situation is different. The Russian Federation does not fall behind the European Union in terms of companies' involvement in e-trading interaction, which is shown in Table 3 and $4[13,14]$. Based on the distribution characteristics of territories, Russia develops more uniformly in terms of e-trading than EU countries. The boundary distribution values minimum and maximum - are almost similar.

Table 3. Characteristics of the regional digital divide in Russia and the EU in terms of indicator "Share of organizations receiving orders for manufactured goods (works, services) on the Internet".

\begin{tabular}{|l|c|c|c|c|}
\hline \multicolumn{1}{|c|}{ Indicator } & $\begin{array}{c}\mathbf{2 0 1 0} \\
\text { Russia }\end{array}$ & EU & $\begin{array}{c}\mathbf{2 0 1 7} \\
\text { Russia }\end{array}$ & EU \\
\hline Maximum value, \% & 39.8 & 34.0 & 31.4 & 30.0 \\
\hline Minimum value, \% & 7.2 & 4.0 & 5.0 & 7.0 \\
\hline Range of variation, p.p. & 32.6 & 30.0 & 26.4 & 23.0 \\
\hline Dispersion & 26.3 & 59.2 & 20.9 & 46.6 \\
\hline Oscillation coefficient, \% & 215.7 & 207.8 & 142.9 & 131.9 \\
\hline Coefficient of variation, \% & 34.0 & 53.3 & 24.7 & 39.2 \\
\hline Gini coefficient, \% & 60.9 & 40.0 & 18.3 & 30.7 \\
\hline Lorentz coefficient, \% & 56.7 & 36.9 & 50.6 & 26.7 \\
\hline
\end{tabular}

Table 4. Characteristics of the regional digital divide in Russia and the EU in terms of indicator "Share of organizations that placed orders for manufactured goods (work, services) on the Internet".

\begin{tabular}{|l|c|c|c|c|}
\hline \multicolumn{1}{|c|}{ Indicator } & $\begin{array}{c}\mathbf{2 0 1 0} \\
\text { Russia }\end{array}$ & EU & $\begin{array}{c}\mathbf{2 0 1 7} \\
\text { Russia }\end{array}$ & EU \\
\hline Maximum value, \% & 58.3 & 54.0 & 5.7 & 57.0 \\
\hline Minimum value, \% & 12.8 & 5.0 & 18.1 & 5.0 \\
\hline Range of variation, p.p. & 45.4 & 49.0 & 32.6 & 52.0 \\
\hline Dispersion & 60.8 & 186.4 & 39.9 & 169.0 \\
\hline Oscillation coefficient, \% & 133.0 & 198.1 & 80.7 & 215.0 \\
\hline Coefficient of variation, \% & 22.8 & 55.2 & 15.6 & 53.7 \\
\hline Gini coefficient, \% & 24.4 & 32.3 & 8.8 & 40.0 \\
\hline Lorentz coefficient, \% & 41.5 & 33.1 & 42.3 & 35.2 \\
\hline
\end{tabular}

Table 5 shows the indicators characterizing electronic business in Russia [14].

Table 5. Use of computers and computer networks by organizations in Russia.

\begin{tabular}{|l|c|c|c|}
\hline \multicolumn{1}{|c|}{ Indicator } & $\mathbf{2 0 1 5}$ & $\mathbf{2 0 1 6}$ & $\mathbf{2 0 1 7}$ \\
\hline $\begin{array}{l}\text { Share of organizations using } \\
\text { personal computers in the total } \\
\text { number of organizations } \\
\text { surveyed }\end{array}$ & 94.5 & 95.5 & 94.8 \\
\hline $\begin{array}{l}\text { Share of organizations using } \\
\text { local area networks in the total } \\
\text { number of organizations } \\
\text { surveyed }\end{array}$ & 70.5 & 70.1 & 68.6 \\
\hline $\begin{array}{l}\text { Share of organizations using } \\
\text { wireless local area networks in } \\
\text { the total number of } \\
\text { organizations surveyed }\end{array}$ & 63.5 & 62.3 & 61.1 \\
\hline $\begin{array}{l}\text { Share of organizations using } \\
\text { Extranet in the total number of } \\
\text { organizations surveyed }\end{array}$ & 16.9 & 15.0 & 16.6 \\
\hline
\end{tabular}




\begin{tabular}{|l|c|c|c|}
\hline $\begin{array}{l}\text { Share of organizations using } \\
\text { third-party open source } \\
\text { operating systems (e.g. Linux) } \\
\text { in the total number of } \\
\text { organizations surveyed }\end{array}$ & 17.3 & 16.6 & 17.3 \\
\hline
\end{tabular}

\section{Discussion}

In 2018, Russia was actively developing the concept of priority measures on improving legal regulation in order to accelerate the development of the digital economy. Lists of the main legal restrictions in force that impede the development of digital economy were prepared, and proposals on their neutralization through changing the current regulatory framework were made. Within the process of normative activity, legal requirements were formulated for restrictions on using paperwork and obsolete technologies when forming, collecting and processing information and taking significant legal actions. At the same time, priority basic legal concepts and institutions necessary for the development of the digital economy were identified. Russia's Global Innovation Index in 2017 - 45 (Figure 1) [15].

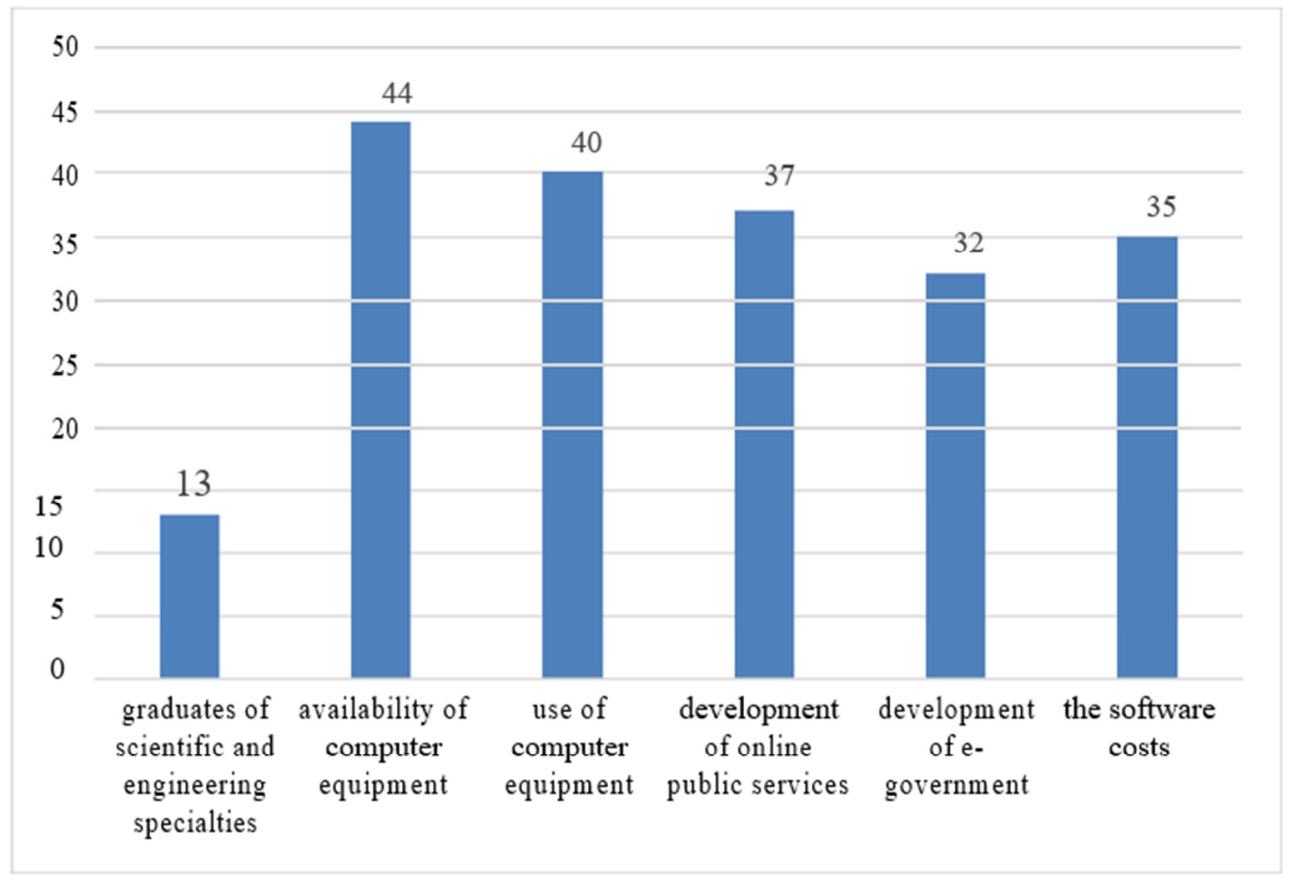

Fig. 1. Global innovation sub-indices of Russia in 2017 (place in the world).

\section{Conclusions}

The main distinguishing feature of digital economies is the widespread introduction of information-and-communication technologies in economic sectors, public sphere and government control. Experts share the view that successful development of the digital economy is of state responsibility, since the state is assigned to coordinate the introduction of advanced technologies [16]. Today, many countries are focusing on government regulation of development of the digital economy and e-trading. According to various 
estimates, the world leaders in the digital economy development are Great Britain, South Korea, China, Denmark, the Netherlands, Sweden, Norway, the USA, Germany and Japan [17].

According to the results of the study and experts' estimates, Russia's development level of broadband Internet access is ranked along with Romania's, Bulgaria's, Greece's and Italy's, which have a low level of broadband access among the countries of the European Union. Despite the initiation of state strategies for the development of the digital economy in Russia, prerequisites for the transition to a new format of economy have not been fully formed. Among the main barriers that prevent the development of the digital economy in Russia, experts highlight the absence of legal regulation and institutional infrastructure, significant digital inequality, insufficient level of information security, shortcomings of the training system of personnel [18].

Experts note the crucial role of the government in centralized accounting and management of implementing the benefits of new technologies [19]. At the moment, the task of determining specific steps to accelerate the digitalization of society remains urgent along with the following questions: what technologies should be applied and how, what are the factors for the effective development of the digital sphere and e-trading, how uniformly is regional development of digital economy provided?

The authors propose to create alternative approaches of regulatory functions for various levels of regulating, forecasting and planning the spatially-temporal development when analyzing indicators of socio-economic growth of the economy by means of the rational economy model, which is designed to create a system of effective interaction of economic entities: economy, economy management, digital infrastructure and economy capabilities. Among the development factors of the Internet economy sector, it is worth highlighting supranational, national and regional factors. The supranational factors include the development of free trade, the desire of companies to do business in foreign countries, ICT innovations, the infrastructure of international transactions. National factors include government stimulation of innovation and support for investment activity; the rule of law, the availability of the necessary technological financial and social infrastructure. Regional factors include infrastructure and access to resources.

It is emphasized that today these tasks are partially being solved, but their final implementation is possible only after identifying sectors of the economy for the introduction of particular digital solutions and the development of target indicators that characterize the effectiveness of introducing the selected technologies in certain industries [20].

In the field of telecommunications, it is proposed to provide the opportunity of making agreements on providing communication services in electronic form, which will allow obligations to originate on the basis on remote actions. This will require the appropriate amendments to be introduced in the Federal Law "On Communications" and various statutory orders on providing communication services made by the Government of the Russian Federation.

In the field of transport, it is advisable for an electronic passport of a vehicle to contain data on its owner and information on a burden imposed by at least one of parties of a pledge agreement, which implies certain amendments to the Civil Code of the Russian Federation. Such information will be put in a system of distributed registries, which will contribute to the transparency of transactions.

In the framework of the third stage, by 2024 the government of the Russian Federation aims to implement the concept of comprehensive legal regulation of relations arising with the development of digital economy. During this period, on the basis of adopted regulatory legal acts, the regulatory environment is to ensure a favorable legal status for the emergence and development of modern technologies and economic activities related to their use in the 
digital economy.

The concept of comprehensive legal regulation of digital economic relations should include:

- basic concepts and principles of legal regulation of the digital economy, aimed at legal support of structural changes in the national economy in order to avoid its dependence on raw materials, stimulation of development of innovative industries that determine scientific and technological progress and increase the competitiveness of domestic products, primarily in digital form;

- features of the implementation of the main activities in the digital economy, the rights and obligations of its participants, types and objects of legal relations, legal facts that determine their occurrence;

- types of responsibility of legal entities in the digital economy and mechanisms for its implementation;

- need for a mandatory assessment of the economic efficiency of draft regulatory legal acts governing relations in the field of development of digital economy;

- issues of legal significance of digital data, inclusive of documents on paper and other digital data;

- introduction of special legal regimes that create conditions for the most comfortable development of organizations operating in priority activities for the digital economy, including economic activity in collecting and using data, and (or) having a certain level of computerization of processes and ready to open them to the state.

Moreover, it is planned to take certain measures on improving standardization mechanisms aimed at ensuring the correspondence of technical regulation system and measurement uniformity with the development goals of digital economy. The measures will work as the "driver" for such development involving the formation of an appropriate regulatory framework and a digital library of existing national standards for priority directions.

\section{References}

1. L. Lazarević, D. Vučković, Z. Popović, Proceedings of the Institution of Mechanical Engineers, Part F: Journal of Rail and Rapid Transit 230(8), 1828-1841 (2016)

2. M. Vilotijević, M. Vukićević, L. Lazarević, Z. Popović, Tehnički vjesnik 25(2), 516523 (2018)

3. L. Lazarević, D. Vučković, M. Vilotijević, Z. Popović, Structural Health Monitoring 18(3), 792-805 (2019)

4. V. Vorobyov, A. Manakov, I. Yanshina, I. Repina, Advances in Intelligent Systems and Computing, VIII International Scientific Siberian Transport Forum 2, 1116 (2020) Doi: 10.1007/978-3-030-37919-3_69

5. E. Voskresenskaya, L. Vorona-Slivinskaya, Y. Tilinin, E3S Web of Conferences 110, 02068 (2019) https://doi.org/10.1051/e3sconf/201911002068

6. E. Voskresenskaya, L. Vorona-Slivinskaya, D. Mokhorov, A. Tebryaev, E3S Web of Conferences 110, 02067 (2019) https://doi.org/10.1051/e3sconf/201911002067

7. E. Voskresenskaya, N. Zhilskiy, E. Shariapova, Matec Web Of Conferences 170, 01057 (2018) DOI https://doi.org/10.1051/matecconf/201817001057

8. E. Voskresenskaya, L. Vorona-Slivinskaya, T. Ponomareva, MATEC Web of Conferences 193, 01028 (2018) https://doi.org/10.1051/matecconf/201819301028

9. Russian Statistics Yearbook (Rosstat., Moscow, 2018)

10. A. Manakov, S. Kolarzh, A. Mashkov, MATEC Web of Conferences 239, 04002 
(2018). DOI: $10.1051 /$ matecconf $/ 201823904002$

11. OECD Digital Economy Outlook 2017 (Summary in Russian) (2017) doi: 10.1787/4657a930-ru

12. V. Vorobyov, A. Manakov, I. Repina, Transport technological processes, MATEC Web of Conferences 239, 08011 (2018) DOI: 10.1051/matecconf/201823908011

13. Manakov, A. Abramov, A. Ilinykh, V. Aksenov, MATEC Web of Conferences 239, 04001 (2018) DOI: 10.1051/matecconf/201823904001

14. T. Vladimirova, A. Manakov, V. Sokolov, MATEC Web of Conferences 216, 02008 (2018) DOI: 10.1051/matecconf/201821602008 